\title{
SIR RICHARD WINSTEDT
}

An era both in Malay studies and in the history of Malaya came to an end when Sir Richard Olaf Winstedt, K.B.E., C.M.G., M.A., D.Litt., LL.D., F.B.A., died at Putney on 2 June 1966. Three years earlier, when he reached his eightyfifth birthday, his long record of scholarship had been honoured with no less than three Festschriften-special issues of the Bulletin of the School of Oriental and African Studies and of the Journal of the Royal Asiatic Society, and a memorable 357-page book entitled Malayan and Indonesian studies to which 19 of Sir Richard's distinguished admirers had contributed essays. Now a tribute was to be paid to another aspect of his work-his unearthing and fostering of the cultural heritage of the Malays from the very early days of modern Malaya until independence and after. When the news of Sir Richard's death became known, Tunku Abdul Rahman sent a telegram to Lady Winstedt expressing his sorrow and concluding: 'My friend, Sir Richard, has done so much throughout his lifetime for the Malays, whom he has always loved. May his soul rest in peace'.

After studying Greats at Oxford the young Winstedt in 1902 joined the Federated Malay States Civil Service (later to be merged into the Malayan Civil Service). He was posted to Perak, a State which had come under British protection only 28 years earlier. At that time the Malays throughout the Peninsula, although a charming and interesting people, were still mainly an illiterate peasantry. Winstedt's interest was fired by the British Resident in Perak, Sir Ernest Birch, and his Secretary, R. J. Wilkinson, the Malay scholar. Wilkinson was to write many years later: 'Sir Ernest held the view that a knowledge of native life and customs was as important to an officer as a knowledge of the vernacular itself. He induced the Government to take up the preparation of a series of "Papers on Malay Subjects" of which he made me the general editor. In carrying out this duty I recall with gratitude the help given me unstintingly by H.H. the Sultan of Perak, his Chiefs (notably Raja Haji Yahya) and his European officers among whom were Messrs. R. O. Winstedt [and others]'. Thus was Winstedt introduced to his lifelong work.

During his Perak period, which was to last some ten years, he soon progressed far beyond merely helping Wilkinson. He himself wrote four of the books in the PMS series-covering Malay folk literature; the circumstances of Malay life; arts and crafts; and fishing, hunting, and trapping respectively. Of these subjects folk literature was the one which most engaged his interest and in this he was aided by Raja Haji Yahya, a man of letters in his own right who had discovered a talented but illiterate story-teller called Pawang Ana. Winstedt capped his PMS book on folk literature with four texts of Pawang Ana's stories (produced in collaboration with A. J. Sturrock), a collection of farcical tales from other Perak story-tellers, and some articles in the Journal of the Straits Branch (later to be called the Malayan Branch) of the Royal Asiatic Society (JSBRAS and JMBRAS), a publication to which he was to contribute 135 times in the course of his life. He now fell ill and was in a primitive hospital for a long time ' cut off from all books of reference except a few Malay classics, 
which I found it an amusement to parse and analyse'. With Wilkinson's encouragement he investigated in depth the basic structure of the language and, when released from hospital and granted long leave, he took his work to Europe for consultation with the established authorities. The result was the publication in 1913 of the first edition of his Malay grammar which, as Dr. Bastin says in Malayan and Indonesian studies, 'established him at the age of 35 among the forefront of British scholars of Malay'. It also brought him into contact with the considerable volume of Dutch scholarship on Malay subjects.

When Winstedt returned from long leave in 1913 he was appointed District Officer in Kuala Pilah, an interesting District which contained the Court of the Yangdipertuan Besar of the Negri Sembilan and also five little States which followed the local version of Minangkabau matrilineal law. During his three years there he studied this customary law, published more texts, and, with Wilkinson, a collection of pantuns, which raised international interest, and also carried his language work further in writing Colloquial Malay : a simple grammar with conversations and An English-Malay dictionary in three volumes. It was during this period that he met the charming Lady Medical Officer, Kuala Pilah, Sara O'Flynn, who was later to become his wife.

In 1916 Winstedt, one of whose appointments in Perak had been as Inspector of Schools, returned to the Education Department, this time (apart from one short interruption) for 15 years. His first title was Assistant Director of Education, Straits Settlements and Federated Malay States, and his task was to improve the system of Malay education. He threw himself into this enthusiastically, visited Java and the Philippines to study educational systems there, and submitted a report which later revolutionized Malay education in Malaya. In 1922 two older teacher-training colleges were replaced with the Sultan Idris Training College at Tanjong Malim, a central institution with a three-year course. Attached to the College was the Malay Translation Bureau. This was designed not only to prepare textbooks but also to provide literature for the graduates of Malay schools. Through these institutions Winstedt was later able not only to improve school education but also to guide the development of the language to cope with modern needs. In 1926 he was made a C.M.G.

Winstedt's translation from ' up-country' to the more academic atmosphere of Education Department headquarters in Singapore led to one of his most productive periods of spare-time writing. He devoted himself especially to educational books and miscellaneous articles for the JSBRAS and the Journal of the Federated Malay States Museums. In 1920 he published a Dictionary of colloquial Malay, the text of the Hikayat Bayan Budiman, and no less than 23 articles covering history, folk-lore, ethnology, philology, literature, and bibliography. But from the time of his marriage in 1921 until the end of his life his Irish wife was to ensure that hard work of this nature was to be relieved and balanced with frequent intervals of merriment.

As part of his work in the Education Department Winstedt in 1921 started a ten-year period as first President of Raffles College, Singapore, the institution

VOL. XXX. PART 1 . 
which, with the King Edward VII College of Medicine, of which he was also a patron, was later to grow into the University of Malaya.

In 1924 he was promoted to be Director of Education, Straits Settlements and Federated Malay States, and a member of the Legislative Council of the Straits Settlements. Until he relinquished duty as Director of Education in 1931 he was highly influential at the policy-making centre of Malaya and the Malays of the independent country of the future were to have every reason to be grateful for this. In the field of scholarship his principal contribution during this period was Shaman, Saiva and Sufi: a study of the evolution of Malay magic (1925).

1931 brought promotion as General Adviser to the Unfederated State of Johore, an appointment which he held for four years. This appears to have stimulated his interest in history and, in addition to many shorter writings, he published the Jawi text of the Tuhfat al-nafis (a Malay history of Riau and Johore), his own original History of Johore, 1365-1895, his History of Selangor, and his Negri Sembilan: the history, polity and beliefs of the Nine States. This work culminated in 1935 in his History of Malaya.

In that same year he retired from the M.C.S. and was made a K.B.E.

On arrival in England he took up an appointment as Lecturer in Malay at what was then called the School of Oriental Studies. In 1937 he was promoted to a Readership. In 1946 he retired from the academic staff at the age of 68, and was elected an Honorary Fellow of the School. He served on the Governing Body of the School first as representative of the Academic Board, and later as representative of the Governments of the Federation of Malaya and of Singapore, from 1938 to 1959.

London brought him into close contact with original records, especially the Raffles Collection of manuscripts in the Library of the Royal Asiatic Society. Three years after his arrival he published in romanized Malay the Raffles manuscript of the Sejarah Melayu 'Malay Annals', which differed in important respects from the manuscripts previously published and opened up interesting possibilities. The following year he published $A$ history of Malay literature which co-ordinated the research of a lifetime in this field.

Then came the war and its aftermath. Winstedt's articles in the Daily Telegraph correctly predicted the fall of Malaya to the Japanese. During the Japanese occupation his Malay-language broadcasts kept hope alive in a country which had every reason to believe that all was lost. Just after the reoccupation, his letter to the Times, written in conjunction with Sir Cecil Clementi and Sir Frank Swettenham, led to the reversal of His Majesty's Government's misguided Malayan Union policy and the institution of a new and enlarged Federal Government which was to guide Malaya to independence 12 years later.

In 1947 Winstedt published The Malays : a cultural history which, like A history of Malay literature, summarized the research of many decades. From then until his death 19 years later he worked on six new dictionaries, the 
preparation of new editions of his most important books, the writing of many more articles and reviews in his chosen fields, and, as a self-effacing tribute to nationalism, a series of anonymous anthologies in Malay. During this period also he devoted himself wholeheartedly to the service of the Royal Asiatic Society of which he was either Director or President from 1940 to 1964 and a regular voluntary helper even after that.

By way of summary and conclusion I now quote two passages from Sir Richard's old friend, Pendita Zainal-'Abidin bin Ahmad. I give the first in translation: 'The fields which he entered ... can be said to comprise almost all branches of Malay culture and civilization from the language and the literature to the beliefs, customs, social organization, way of life, economy, arts and crafts, undertakings, industries, amusements, and history of the Malays of Malaya'. The second passage is :

\section{Hutang emas boleh di-bayar; \\ Hutang budi di-bawa mati -}

'A debt of gold can be repaid ; a debt of gratitude is carried for ever'.

E. C. G. BARRETT 